\title{
Сорбционные свойства модифицированного глауконита
}

\author{
(C) 2021 Перегудов Ю.С., Горбунова Е.М., Мэжри Р., Нифталиев С.И. \\ Воронежский государственный университет инженерных технологий, Воронеж
}

Поступила в редакцию 9.10.2020 г.

DOI: $10.17308 /$ sorpchrom.2021.21/3219

Модифицирование минералов позволяет получить новые сорбционные материалы, обладающие улучшенными свойствами, что расширяет области успешного их применения. Целью исследования являлась разработка способов получения новых модифицированных сорбентов на основе глауконита, определение их количественного состава и сорбционных свойств. Химическая активность сорбента зависит от количества и природы активных центров, участвующих в сорбционном процессе. Число активных центров глауконита было, изменено путём термической активации при температуре 600 и $1000^{\circ} \mathrm{C}$. Анализ полученных данных индикаторного метода показал, что на поверхности выявлены различные по силе центры адсорбции образцов глауконита при $\mathrm{p} K \mathrm{a}+2.1,+5.2$, находящиеся в области кислот Бренстеда. Для исходных образцов глауконита преобладают основные центры Бренстеда при $\mathrm{pKa}=+9.4$. Термическая активация глауконита уменьшает величину удельной адсорбции. Также показано, что модифицирование и термическая обработка глауконита приводят к уменьшению удельной поверхности, истинной плотности и росту среднего диаметра частиц.

Образец глауконита модифицированного оксидом марганца (IV) показал более высокие значения сорбции ионов железа (III) по сравнению с немодифицированным и термически активированным образцами. Предложена технологическая схема получения глауконита модифицированного оксидом марганца (IV) в гранулированном виде для очистки подземных артезианских вод с повышенным содержанием железа (III). Исходные и термические активированные образцы глауконита подвергали модифицированию натриевой солью карбоксиметилцеллюлозы. Гранулированные формы полученных модифицированных сорбентов применяли для изучения поглощения нефти и нефтепродуктов. Установлено, что лучшие сорбционные свойства показал образец, подвергающийся, термической активации при $1000^{\circ} \mathrm{C}$. При данной температуре происходят значительные структурные изменения глауконита, сопровождающиеся образованием большого количества дефектов. При модифицировании натриевая соль карбоксиметилцеллюлозы заполняет эти дефекты, что способствует поглощению нефти и нефтепродуктов. Полученные результаты показали, что модифицирование и термическая активация природного минерала по-разному влияют на сорбцию иона железа (III) и нефтепродуктов.

Ключевые слова: глауконит, кислотно-основные центры, термическая активация, модифицирование глауконита, оксид марганца (IV), целлюлозосодержащий компонент, сорбция, нефтепоглощение.

\section{Введение}

Природные минералы, обладая уникальными сорбционными свойствами, нашли широкое применение впроцессах очистки сточных вод. Одной из характеристик, наилучшим образом отражающих реакционную способность поверх- ности в донорно-акцепторных взаимодействиях, являются кислотно-основные свойства, в которых проявляются практически все фундаментальные параметры и функциональные свойства твердого вещества [1]. Поверхность адсорбентов представлена совокупностью центров Бренстеда и Льюиса, как основного, так и 
кислотного типа [2]. Авторы [3] исследовали кислотно-основные свойства поверхности монтмориллонита индикаторным методом и методом инфракрасной спектроскопии. При нагревании образцов до $600^{\circ} \mathrm{C}$ общее количество кислотных центров на поверхности монтмориллонита увеличивалось. В работе [4] изучен процесс ионного обмена на глинистых материалах и дана оценка влияния $\mathrm{pH}$ и температуры на обменную емкость глин Иркутской области. Изучение активных центров позволяет прогнозировать каталитическую и сорбционную способность поверхности глин, механизм хроматографического удерживания и разделения в зависимости от условий модификаций $[5,6]$.

Известно, что активация и модифицирование минералов приводит к изменению их структурных и сорбционных характеристик [7-10]. Исследована адсорбция хромат ионов на природных клиноптилолите, глауконите и монтмориллоните, обработанных бромидом гексадецилтриметиламмония. При начальной концентрации хромат ионов 6.25 ммоль/дм ${ }^{3}$ модифицированные клиноптилолит, глауконит и монтмориллонит поглощали 47, 102 и 168 ммоль / кг соответственно [11]. Для приготовления адсорбентов на основе глауконита используют смеси глауконитового песка и дигидрофосфата натрия $\mathrm{NaH}_{2} \mathrm{PO}_{4}$ в различных весовых соотношениях. Сорбционная емкость адсорбентов возрастает с увеличением содержание кислой соли [12]. Для удаления фторид-ионов из водных сред применяли нанокомпозиты глауконитовой глины и модифицированного хитозана. Хитозан модифицировали этилендиаминтетрауксусной кислотой, глутаровым альдегидом, додецилсульфатом натрия и цетилтриметиламмоний бромидом. Максимальное значение адсорбционной емкости 9.03 мг/г показал последний сорбент [13]. Представлены результаты исследования селективности сорбции цезия природным и поверхностно- модифицированным глауконитом в зависимости от концентраций солей калия и аммония. Для поверхностно-модифицированного глауконита при низком содержании солей наблюдалось снижение коэффициентов распределения цезия [14]. Поверхностно модифицированные минералы (бентонит и глауконит) использовались при удалении красителей из текстильных сточных вод. Установлено, что полное удаление красителя достигалось при использовании 10-25 г модифицированного глауконита из растворов с концентрацией красителя $10-50 \quad$ мг/дм ${ }^{3}$ $[15,16]$.

\section{Экспериментальная часть}

В качестве объекта исследования использовался глауконит Каринского месторождения Челябинской области, его химический, оксидный и фазовый состав представлен в работе [17]. Лучшие результаты по сорбции нефтепродуктов показала фракция глауконита с размером частиц 0.045-0.1 мм, которая была выбрана как основа для получения сорбентов.

Для определения кислотно-основных свойств поверхности образцов применялся индикаторный метод Танабе и Гаммета $[2,18]$. Адсорбция индикаторов на поверхности веществ позволяет определить качественный состав и концентрацию активных центров, а также распределение активных центров по силе. В работе использовались кислотно-основные индикаторы [18], основные характеристики которых приведены в таблице 1.

Методика эксперимента заключалась в следующем. Для каждого образца глауконита готовили три параллельных пробы: 0.1 г порошка анализируемого состава смешивали с 3 см ${ }^{3}$ индикатора; 0.1 г порошка анализируемого состава смешивали с $2 \mathrm{~cm}^{3}$ воды дистиллированной (холостая проба); раствор чистого индикатора объемом $3 \mathrm{~cm}^{3}$. Пробы хорошо перемешивались и выдерживались в течение суток при температуре $20^{\circ} \mathrm{C}$. Затем перед измерением в три параллельные пробы и 
Таблица 1. Характеристика кислотно-основных индикаторов

Table 1. Characteristics of acid-base indicators

\begin{tabular}{|c|c|c|c|c|}
\hline Название & Формула & $\begin{array}{c}\text { Молярная } \\
\text { масса, г/моль }\end{array}$ & $\mathrm{p} K_{\mathrm{a}}$ & $\begin{array}{c}\text { Длина волны } \\
\text { максимального } \\
\text { поглощения, } \lambda, \\
\text { нм }\end{array}$ \\
\hline Бриллиантовый зеленый & $\mathrm{C}_{29} \mathrm{H}_{37} \mathrm{~N}_{2} \mathrm{O}_{4}$ & 475.60 & 1.3 & 610 \\
\hline Фуксин основной & $\mathrm{C}_{20} \mathrm{H}_{20} \mathrm{~N}_{3} \mathrm{Cl}$ & 323.83 & 2.1 & 540 \\
\hline Метиловый оранжевый & $\mathrm{C}_{14} \mathrm{H}_{14} \mathrm{~N}_{3} \mathrm{O}_{3} \mathrm{SNa}$ & 327.32 & 3.46 & 464 \\
\hline Метиловый красный & $\mathrm{C}_{15} \mathrm{H}_{15} \mathrm{~N}_{3} \mathrm{O}_{2}$ & 296.30 & 5.2 & 530 \\
\hline Бромтимоловый синий & $\mathrm{C}_{27} \mathrm{H}_{28} \mathrm{Br}_{2} \mathrm{O}_{5} \mathrm{~S}$ & 624.38 & 7.4 & 540 \\
\hline Фенолфталеин & $\mathrm{C}_{20} \mathrm{H}_{14} \mathrm{O}_{4}$ & 318.23 & 9.4 & 440 \\
\hline Индиго кармин & $\mathrm{C}_{16} \mathrm{H}_{8} \mathrm{~N}_{2} \mathrm{Na}_{2} \mathrm{O}_{8} \mathrm{~S}_{2}$ & 422.38 & 12.8 & 610 \\
\hline
\end{tabular}

пробы чистого индикатора добавлялось по $2 \mathrm{~cm}^{3}$ воды и пробы перемешивались, а в холостую пробу добавлялось $3 \mathrm{~cm}^{3}$ индикатора, и проба также перемешивалась. Растворы использовались для дальнейших исследований на фотоколориметре КФК-2МП. Расчет удельной адсорбции g, моль/г проводили по формуле (1):

$$
g=\frac{c \cdot V}{D_{0}} \cdot\left|\frac{\left|D_{0}-D_{1}\right|}{a_{1}} \pm \frac{\left|D_{0}-D_{2}\right|}{a_{2}}\right|
$$

где с - концентрация индикатора, моль/дм ${ }^{3} ; \mathrm{V}$ - объем пробы, дм³ $; \mathrm{D}_{0}$ - оптическая плотность исходного индикатора; $\mathrm{D}_{1}$ - оптическая плотность индикатора после сорбции образцом; $\mathrm{D}_{2}$ - оптическая плотность холостой пробы (растворитель + образец материала); $\mathrm{a}_{1}, \mathrm{a}_{2}$ - навески образца, г.

Слоистая структура поверхности зерен глауконита позволяет нанесение и удерживание плёнки из оксигидратов многовалентных металлов. Модифицирование глауконита солями марганца осуществлялось следующим образом. Вначале осуществляли термическую активацию глауконита в электропечи ЭКПС-10 при $1000^{\circ} \mathrm{C}$ в течение 2 часов. Затем в течение 6 часов образцы исходного и термически активированного глауконита промывались раствором соляной кислоты с массовой долей $1 \%$, после чего отмывались водой до отрицательной реакции на ион хлора и высушивались при температуре $105-110^{\circ} \mathrm{C}$ в сушильном шкафу. Затем образцы глауконита обрабатывались раствором перманганата калия с массовой долей $1 \%$, после раствором хлорида марганца (II) с массовой долей 15\%. После этого образцы промывались раствором персульфата аммония до отрицательной реакции на ион марганца. В основе модифицирования глауконита лежит реакция восстановления перманганата калия хлоридом марганца (II):

$$
\begin{gathered}
3 \mathrm{MnCl}_{2}+2 \mathrm{KMnO}_{4}+2 \mathrm{H}_{2} \mathrm{O} \\
\rightarrow 2 \mathrm{KCl}+5 \mathrm{MnO}_{2}+4 \mathrm{HCl}
\end{gathered}
$$

Для получения гранулированного сорбента использовалась натриевая соль карбоксиметилцеллюлозы (Na-КМЦ), характеризующаяся низкой ценой, биологической разлагаемостью и экологичностью. К исходному и термически активированным образцам глауконита при 600 и $1000^{\circ} \mathrm{C}$ добавляли 5мас.\% Na-КМЦ, воду, перемешивали и продавливали через фильеру с диаметром отверстий 3 мм.

Измерение удельной поверхности производилось с помощью прибора ПСХ $11 \mathrm{~A}$, определяющего время прохождения фиксированного объема воздуха через слой образца.

Для определения истинной плотности образцов глауконита использовали пикнометрический метод. Истинную плотность глауконита ( $\rho)$ в г/ $\mathrm{cm}^{3}$ вычисляли по формуле (2)

$$
\rho=\frac{\left(m-m_{1}\right) \cdot \rho_{\mathrm{B}}}{m-m_{1}+m_{2}-m_{3}}
$$

где $\mathrm{m}$ - масса пикнометра с глауконитом, г; $\mathrm{m}_{1}$ - масса пустого пикнометра, г; m2 - масса пикнометра с дистиллированной водой, г;m3 - масса пикнометра с гла- 
уконитом и дистиллированной водой после удаления пузырьков воздуха, г; $\rho_{\text {в }}$ плотность воды, равная $1 \mathrm{r} / \mathrm{cm}^{3}$.

Концентрацию ионов железа (III) определяли спектрофотометрически. Сорбционную емкость (А, ммоль/г) в условиях установившегося в системе равновесия определяли по формуле (3):

$$
\mathrm{A}=\frac{\left(\mathrm{C}-\mathrm{C}_{\mathrm{p}}\right) \cdot V}{m}
$$

где $\mathrm{C}, \mathrm{C}_{\mathrm{p}}$ - исходная и равновесная концентрация ионов железа (III) в растворе соответственно, ммоль/дм ${ }^{3} ; \mathrm{V}$ - объем раствора, дм ${ }^{3} ; \mathrm{m}$ - масса сорбента, г.

Нефтепоглощение (А, \%) рассчитывали по формуле (4):

$$
\mathrm{A}=\frac{\mathrm{P}_{\mathrm{T}}-\mathrm{P}_{0}}{\mathrm{P}_{0}} \cdot 100,
$$

где $\mathrm{P}_{\mathrm{T}}-$ вес сорбента после погружения в нефть, г; $\mathrm{P}_{0}$ - первоначальный вес сорбента, г.

В качестве загрязнителей были выбраны ионы железа (III), нефть II, бензин A-92 и синтетическое масло Castrol $5 \mathrm{w}-40$. Потери бензина при измерениях составили $6.61 \%$, нефти $-0.57 \%$.

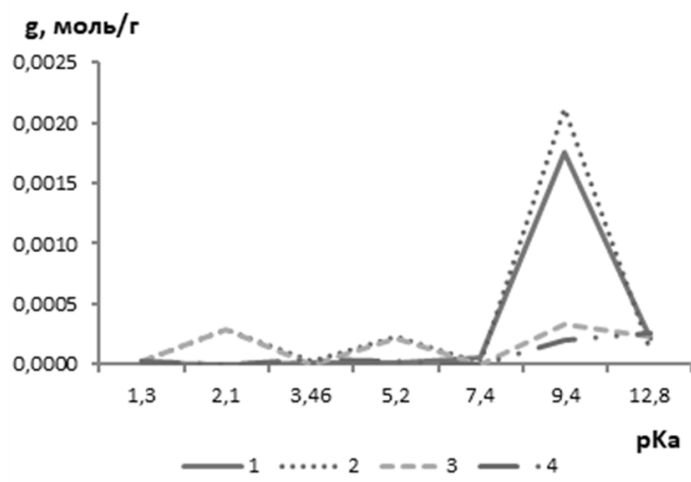

Рис. 1. График зависимости удельной адсорбции образцов глауконита от значения $\mathrm{pK}_{\mathrm{a}}$ индикатора: 1 - глауконит исходный, 2 - глауконит 0.045-0.1 мм, 3 - глауконит термически активированный при $600^{\circ} \mathrm{C}$,

4 - глауконит термически активированный при $1000^{\circ} \mathrm{C}$

Fig. 1. Graph of the dependence of the specific adsorption of glauconite samples on the $\mathrm{pK}_{\mathrm{a}}$ of the indicator: 1 - initial glauconite, $2-$ glauconite $0.045-0.1 \mathrm{~mm}, 3$ - thermally activated glauconite at $600^{\circ} \mathrm{C}, 4-$ thermally activated glauconite at $1000^{\circ} \mathrm{C}$
Целью данной работы являлась разработка способов получения новых модифицированных сорбентов на основе глауконита, определение их количественного состава и эксплуатационных свойств.

\section{Обсуждение результатов}

Химическая активность сорбента зависит от количества и природы активных центров, участвующих в сорбционном процессе. Число активных центров глауконита было изменено путём термической активации. По полученным данным индикаторного метода был построен график зависимости удельной адсорбции образцов глауконита от величины $\mathrm{p} K_{\mathrm{a}}$ индикатора (рис. 1). Получена картина распределения активных центров на поверхности с дифференциацией по силе.

Анализ полученных данных свидетельствует о том, что на поверхности выявлены различные по силе центры адсорбции образцов глауконита при $\mathrm{p} K_{\mathrm{a}}$ $+2.1,+5.2$, находящиеся в области кислот Бренстеда. У исходных образцов глауконита преобладают основные центры

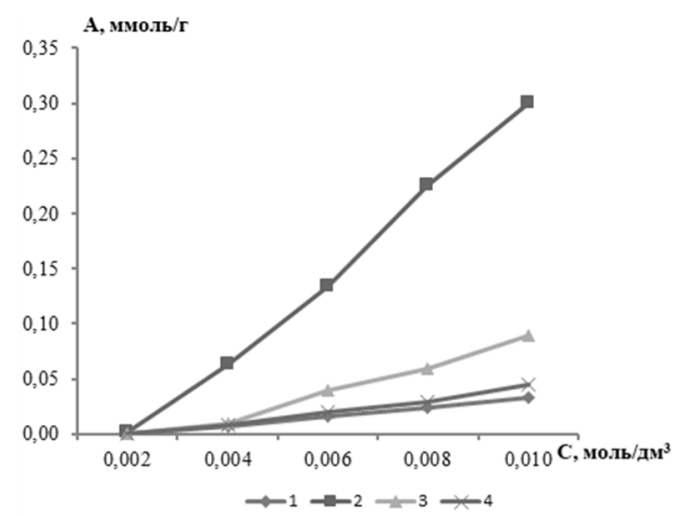

Рис. 2. Изотермы сорбции ионов железа (III) образцами глауконита: 1 - исходный глауконит, 2 - модифицированный марганцем глауконит, 3 - термически активированный при $1000^{\circ} \mathrm{C}$ и модифицированный марганцем глауконит, 4 -термически активированный при $1000^{\circ} \mathrm{C}$ глауконит.

Fig. 2. Sorption isotherms of iron (III) ions by glauconite samples: 1 - initial glauconite, 2 - manganese-modified glauconite, 3 - thermally activated at $1000^{\circ} \mathrm{C}$ and manganesemodified glauconite, 4 - glauconite thermally activated at $1000^{\circ} \mathrm{C}$. 
Таблица 2. Результаты измерений удельной поверхности и истинной плотности

Table 2. Specific surface area and real density measurements

\begin{tabular}{|c|c|c|c|c|c|c|c|}
\hline \multicolumn{2}{|r|}{ Номер образца } & 1 & 2 & 3 & 4 & 5 & 6 \\
\hline \multirow{5}{*}{ 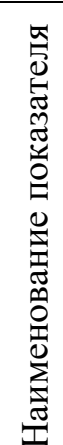 } & $\begin{array}{c}\text { Удельная поверх- } \\
\text { ность, } \text { см}^{2} / \Gamma\end{array}$ & 7257 & 6399 & 3270 & 1552 & 1490 & 1430 \\
\hline & $\begin{array}{c}\text { Средний диаметр ча- } \\
\text { стиц, мкм }\end{array}$ & 3.1 & 4.1 & 7.0 & 15.0 & 21.8 & 23.6 \\
\hline & $\begin{array}{c}\text { Абсолютное откло- } \\
\text { нение, } \mathrm{cm}^{2} / \Gamma\end{array}$ & \pm 4.1 & \pm 6.3 & \pm 2.3 & \pm 9.2 & \pm 1.4 & \pm 1.2 \\
\hline & $\begin{array}{c}\text { Относительное от- } \\
\text { клонение, \% }\end{array}$ & \pm 0.1 & \pm 0.1 & \pm 0.1 & \pm 0.1 & \pm 0.1 & \pm 0.1 \\
\hline & $\begin{array}{c}\text { Истинная плотность, } \\
\Gamma / \mathrm{cm}^{3}\end{array}$ & 2.71 & 2.31 & 2.62 & 2.57 & 1.84 & 2.14 \\
\hline
\end{tabular}

Бренстеда при $\mathrm{p} K_{\mathrm{a}}=+9.4$. При нагревании до 600 и $1000^{\circ} \mathrm{C}$ происходит дегидратация, изменяющая структуру минерала, что уменьшает величину удельной адсорбции. Полученные результаты свидетельствуют о том, что образцы глауконита 1 и 2 (рис. 1) относятся к кислотным катализаторам.

Для анализа удельной поверхности подвергались следующие образцы: 1 - глауконит с размером частиц 0.0450.1 мм, 2 - глауконит с размером частиц $0.045-0.1$ мм обожженный при $600^{\circ} \mathrm{C}$, 3 - глауконит с размером частиц 0.045 0.1 мм обожженный при $1000^{\circ} \mathrm{C}, 4$ - глауконит с размером частиц 0.045-0.1 мм модифицированный (5\% Na КМЦ), 5 - глауконит с размером частиц 0.045-0.1 мм обожженный при $600^{\circ} \mathrm{C}$ модифицированный (5\% Na КМЦ), 6- глауконит с размером частиц $0.045-0.1$ мм обожженный при $1000^{\circ} \mathrm{C}$ модифицированный $(5 \% \mathrm{Na}-$ КМЦ). Анализ полученных данных показал, что термическая активация и модифицирование приводят к уменьшению удельной поверхности, истинной плотности и росту среднего диаметра частиц (табл. 2).

Модифицированные образцы глауконита использовали для изучения сорбции ионов железа (III) из водных растворов (рис. 2). Как видно из рис. 2, образцы глауконита по росту сорбционной способности можно расположить в следующий ряд: исходный глауконит, термически активированный при $1000^{\circ} \mathrm{C}$ глауконит, термически активированный при $1000^{\circ} \mathrm{C}$ и модифицированный оксидом марганца (IV) глауконит, исходный глауконит модифицированный оксидом марганца (IV).Термическая активация не привела к значительному увеличению сорбционных свойств природного глауконита, т.к. удаляется межслоевая и кристаллизационная вода, что приводит к уменьшению межслоевого расстояния и снижению числа сорбционных центров.

Для получения химически модифицированного глауконита для очистки воды от ионов железа (III) предложена следующая технологическая схема (рис. 3).

Согласно технологической схемы глауконит направляется в молотковую дробилку и на вибрационные сита для получения фракции от 0.045 до 0.1 мм. Данная фракция глауконита подвергается кислотной обработке с дальнейшей промывкой и сушкой при комнатной температуре с использованием вентилятора. Нанесение плёнки оксида марганца осуществляют $1 \%$ раствором перманганата калия $\mathrm{KMnO}_{4}$, далее обрабатывают 15\% раствором хлорида марганца $\mathrm{MnCl}_{2}$, смесь перемешивается, промывается, высушивается и подается на грануляцию с карбоксиметилцеллюлозой. Гранулированный модифицированный оксидом марганца (IV) сорбент может быть использован в качестве загрузки в фильтры для очистки подземных артезианских вод с повышенным содержанием железа (III). При этом сорбент будет поглощать частицы железа за счёт физической и химической сорбции. 


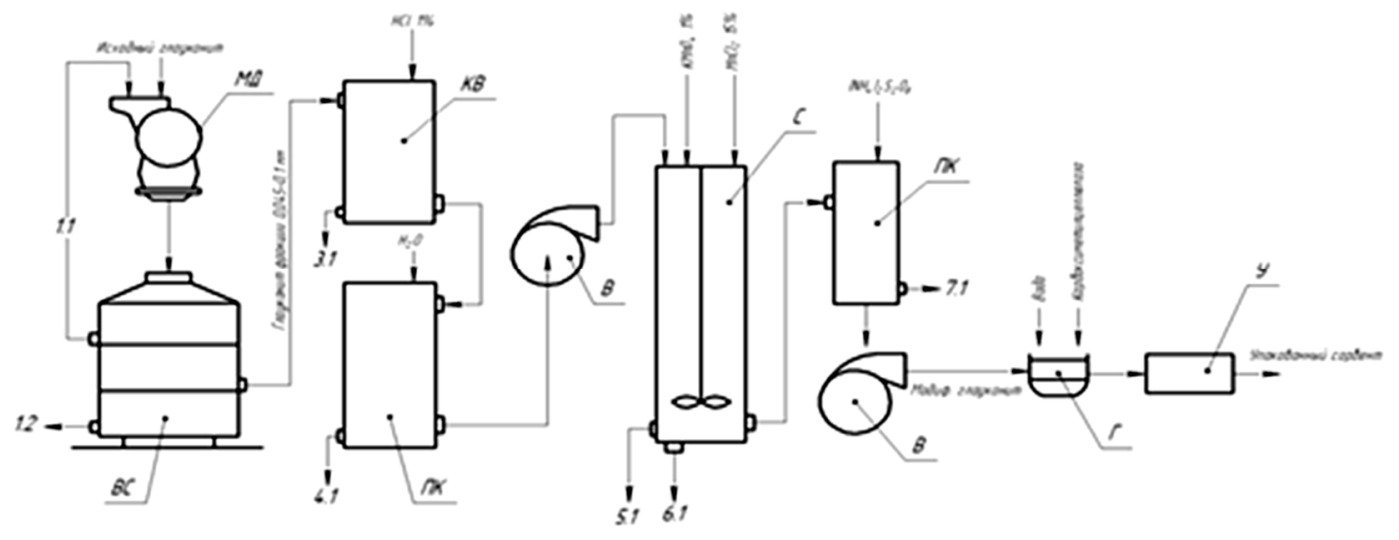

Рис. 3. Технологическая схема получения глауконита модифицированного оксидом марганца (IV), где МД - молотковая дробилка, ВС - вибрационные сита, КВ - кислотная ванна, ПК - промывная колонна, В - вентилятор, С - смеситель, Г - гранулятор, УП - упаковочный автомат; 1.1 - глауконит фракции $>0.1$ мм, 1.2 - глауконит фракции $<0.045$ мм, 3.1 - отработанный раствор $\mathrm{HCl}, 4.1$ - очищенная вода, 5.1 - отработанный раствор $\mathrm{KMnO}_{4} 1 \%$,

6.1 - отработанный раствор $\mathrm{MnCl}_{2} 15 \%, 7.1$ - отработанный раствор $\left(\mathrm{NH}_{4}\right)_{2} \mathrm{~S}_{2} \mathrm{O}_{8}$.

Fig. 3. Technological scheme for the production of glauconite modified with manganese oxide (IV), where HM - hammer mill, VS - vibrating sieves, AB - acid bath, WC - washing column, $\mathrm{F}$ - fan, $\mathrm{M}$ - mixer, $\mathrm{G}$ - granulator, $\mathrm{PM}$ - packing machine; 1.1 - glauconite fraction $>0.1 \mathrm{~mm}$, 1.2 - glauconite fraction $<0.045 \mathrm{~mm}, 3.1$ - waste $\mathrm{HCl}$ solution, 4.1 - purified water, 5.1 - waste solution $\mathrm{KMnO}_{4} 1 \%, 6.1$ - waste solution $\mathrm{MnCl}_{2} 15 \%, 7.1$ - waste solution $\left(\mathrm{NH}_{4}\right)_{2} \mathrm{~S}_{2} \mathrm{O}_{8}$.

Следующим этапом исследования было изучение нефтепоглощения сорбентами, полученными модифицированием Na-КМЦ образцов глауконита. Данные

сорбенты были в гранулированном виде. Результаты сорбции нефти и нефтепродуктов гранулированными сорбентами

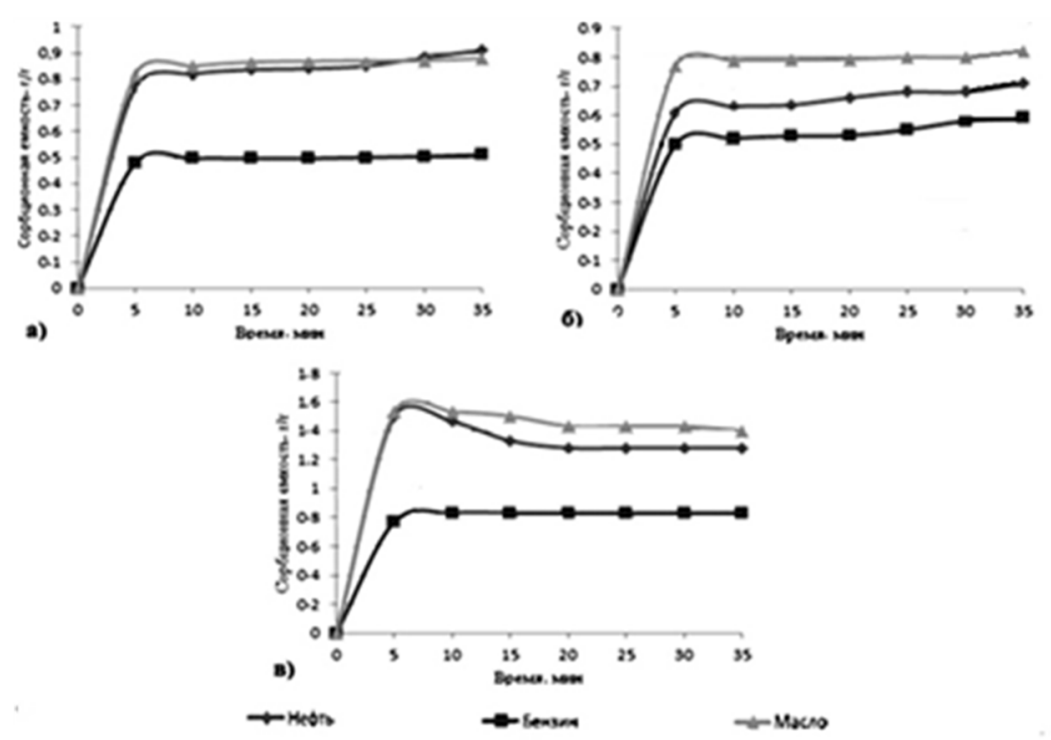

Рис.4. Зависимость поглощения нефти, масла, бензина от времени контакта образцов глауконита, обработанных Na-КМЦ: а - фракция глауконита (0.045-0.1 мм); б - фракция глауконита (0.045-0.1 мм) обработанного при температуре $600^{\circ} \mathrm{C}$; в - фракция глауконита (0.045-0.1 мм) обработанного при температуре $1000^{\circ} \mathrm{C}$

Fig. 4. Dependence of the absorption of oil-fuel, oil, gasoline on the contact time of samples/glauconite treated with Na-CMC: a - glauconite fraction $(0.045-0.1 \mathrm{~mm}) ; \mathrm{b}-$ glauconite fraction $(0.045-0.1 \mathrm{~mm})$ treated at a temperature of $600^{\circ} \mathrm{C} ; \mathrm{c}-$ glauconite fraction $(0.045-0.1 \mathrm{~mm})$ treated at a temperature of $1000^{\circ} \mathrm{C}$ 
представлены на рисунке 4. Модифицирование Na-КМЦ увеличивает сорбционную емкость глауконита. Лучшие показатели наблюдались для сорбентов, термически активированных при температуре $1000^{\circ} \mathrm{C}$

При температуре $1000^{\circ} \mathrm{C}$ на поверхности частиц глауконита образуется значительное количество дефектов в виде трещин [17]. При модифицировании данные трещины заполняются большим количеством Na-КМЦ, что и способствует поглощению нефтепродуктов. Данные гранулированные модифицированные сорбенты очень быстро поглощают нефть. Установлено, что время полного поглощения нефти данным сорбентом составило 2 минуты.

\section{Список литературы}

1. Танабе К. Твердые кислоты и основания. М. Мир. 1973. 184 c.

2. Пахнутова Е.А., Слижов Ю.Г. // Журнал физической химии. 2014. Т. 88. № 7-8, С. 1228-1232. DOI: $10.7868 / \mathrm{S} 0044453714080226$

3. Dong Liu, Peng Yuan, Hongmei Liu, Jingong Cai et al. // Applied Clay Science. 2011. Vol. 52. pp. 358-363.

4. Во Дай Ту // Известия вузов. Прикладная химия и биотехнология. 2011. № 1. С.49-53.

5. Adams J.M., Mccabe R.W. // Handbook of Clay Science. Developmentsin ClayScience. 2006. Vol. 1. pp. 541-565.

6. Нифталиев С.И., Горбунова Е.М., Перегудов Ю.С., Кузнецова И.В. и др. // Химическая промышленность сегодня. 2020. № 1. С. 48-53.

7. Бельчинская Л.И., Козлов К.А., Бондаренко А.В., Петухова Г.А. и др. // Сорбиионные и хроматографические прочессы. 2007. T. 7. № 4. C. 571-576.

8. Новикова Л.А., Бельчинская Л.И., Крупская В.В., Ресснер Ф. и др. // Сорбиионные и хроматографические прочессы. 2015. Т.15. № 5. С. 730-740.

9. Бельчинская Л.И., Стрельникова О.Ю., Ходосова Н.А., Ресснер Ф. // Хімія, фізика та технологія поверхні. 2013. Т. 4. № 4. С. 420426.

10. Бельчинская Л.И., Петухова Г.А., Козлов К.А., Бондаренко А.В. и др. // Журнал

\section{Заключение}

Полученные результаты показали, что модифицирование и термическая активация природного минерала по-разному влияют на сорбцию иона железа (III) и нефтепродуктов. При исследовании сорбции ионов железа (III) образец глауконита модифицированного оксидом марганца (IV) показал более высокие значения по сравнению с не модифицированным и термически активированным образцами. Лучшие сорбционные свойства по нефтепродуктам показал глауконит, термически активированный при $1000{ }^{\circ} \mathrm{C}$ и модифицированный карбоксиметилцеллюлозой.

прикладной химии. 2008. Т. 81. № 6. С. 926930.

11. Bajda T., Klapyta Z. // Applied Clay Science. 2013. Vol. 86. pp 169-173. https://doi.org/10.1016/j.clay.2013.10.005

12. Kuanysheva G.S., Balgysheva B.D., Asilov A.B., Uraraev F.KH. // Chemistry for Sustainable Development. 2014. Vol. 22. pp. 37-42.

13. SobeihM.M., El-ShahatM.F., OsmanA., ZaidM.A. et al. // RSCAdv. 2020. Vol. 10. pp. 25567-25585. https://doi.org/10.1039/ D0RA02340

14. Semenishchev V.S., Ryabukhina V.G., Voronina A.V., Mashkovtsev M.A. и др. // Journal of Radio analytical and Nuclear Chemistry. 2016. Vol. 309. pp. 583-588.

15. Selim K.A., Youssef M.A., El-Rahiem F.H.Abd, Hassan M.S. // International Journal of Mining Science and Technology. 2014. Vol. 24ю pp. 183-189. https://doi.org/10.1016/ j.ijmst.2014.01.007

16. Selim K.A., Youssef M.A., Hassan M.S., El-Rahiem F.H. Abd. // Journal of Ore Dressing. 2013. Vol. 15. pp. 21-32.

17. Нифталиев С.И., Перегудов Ю.С., Мокшина Н.Я., Мэжри Р. и др. . // Экология и промышленность России. 2019. Т. 23. № 7. С. 4247. https://doi.org/10.18412/1816-0395-2019-742-47

18. Кравцов А.А., Семенова Н.С., Блинов А.В., Ясная М.А. и др. // Вестник Кемеровского государственного университета. 2015. T. 3. № 4 (64). C. 237-244. 


\title{
Sorption properties of modified glauconite
}

\author{
(C) 2021 Peregudov Yu.S., Gorbunova E.M., Mejri R., Niftaliev S.I.
}

\author{
Voronezh State University of Engineering Technologies, Voronezh, Russian Federation
}

The modification of minerals allows obtaining new sorption materials with improved properties, expanding the areas of their successful application. The aim of the study was the development of methods for obtaining new modified sorbents based on glauconite, the determination of their quantitative composition and sorption properties. The chemical activity of the sorbent depends on the number and nature of the active centres involved in the sorption process. The number of active centres of glauconite was changed by thermal activation at temperatures of 600 and $1000^{\circ} \mathrm{C}$. The analysis of the obtained data of the indicator method showed that adsorption centres with different strength at $\mathrm{pKa}+2.1,+5.2$, located in the region of Bronsted acids were revealed on the surface of the glauconite samples. For the initial glauconite samples, the main Bronsted centres prevailed at $\mathrm{pKa}=+9.4$. The thermal activation of glauconite reduced the specific adsorption value. Also, it was shown that the modification and heat treatment of glauconite led to a decrease in the specific surface area and real density and an increase in the average particle diameter.

Glauconite sample modified with manganese (IV) oxide showed higher values of sorption of iron (III) ions in comparison with unmodified and thermally activated samples. A technological scheme for obtaining glauconite modified with manganese (IV) oxide in granular form for the purification of underground artesian waters with an increased content of iron (III) was proposed. The initial and thermally activated glauconite samples were modified with the sodium salt of carboxymethylcellulose. Granular forms of the obtained modified sorbents were used to study the absorption of oil and oil products. It was found that the best sorption properties were shown by a sample subjected to thermal activation at $1000{ }^{\circ} \mathrm{C}$. At this temperature, significant structural changes, accompanied by the formation of a large number of defects, occurred in glauconite. The sodium salt of carboxymethyl cellulose fills these defects when modified, promoting the absorption of oil and oil products. The obtained results showed that the modification and thermal activation of a natural mineral have different effects on the sorption of iron (III) ions and oil products.

Keywords: glauconite, acid-base centres, thermal activation, modification of glauconite, manganese (IV) oxide, cellulose-containing component, sorption, oil absorption.

\section{References}

1. Tanabe K. Tverdye kisloty I osnovanija. M/, Mir, 1973. $184 \mathrm{p}$.

2. Pahnutova E.A., Slizhov Ju.G., Zhurnal fizicheskojhimii, 2014, Vol. 88, No 7-8, pp. 12281232. DOI: $10.7868 / \mathrm{S} 0044453714080226$

3. Dong Liu, Peng Yuan, Hongmei Liu, Jingong Cai et al., Applied Clay Science, 2011, Vol. 52, pp. 358-363.

4. Vo Daj Tu, Izvestija vuzov. Prikladnaja khimija I biotekhnologija, 2011, No 1, pp.49-53.

5. Adams J.M., Mccabe R.W., Handbook of Clay Science. Development in Clay Science, 2006, Vol. 1, pp. 541-565.

6. Niftaliev S.I., Gorbunova E.M., PeregudovJu.S., Kuznecova I.V. et al., Khimicheskaja promyshlennost' segodnja, 2020, No 1, pp. 48-53.

7. Bel'chinskaja L.I., Kozlov K.A., Bondarenko A.V., Petuhova G.A. et al., Sorbtsionnye i khromatograficheskie protsessy, 2007, Vol. 7, No 4, pp. 571-576.

8. Novikova L.A., Bel'chinskaja L.I.,
Krupskaja V.V., Ressner F. et al., Sorbtsionnye $i$ khromatograficheskie protsessy, 2015, Vol. 15, No 5, pp. 730-740.

9. Bel'chinskaja L.I., Strel'nikova O.Ju., Khodosova N.A., Roessner F. Khimija, fizika ta tekhnologija poverhni, 2013, Vol. 4, No 4, pp. 420-426.

10. Bel'chinskaja L.I., Petuhova G.A., Kozlov K.A., Bondarenko A.V. et al., Zhurnal prikladnojhimii, 2008, Vol. 81, No 6,pp. 926-930.

11. Bajda T., Klapyta Z., Applied Clay Science, 2013, Vol. 86, pp. 169-173. https://doi.org/10.1016/j.clay.2013.10.005

12. Kuanysheva G.S., Balgysheva B.D., Asilov A.B., Uraraev F.KH. Chemistry for SustainableDevelopment, 2014, Vol. 22, pp. 37-42.

13. Sobeih M.M., El-Shahat M.F., Osman A., Zaid M.A. et al., RSCAdv, 2020, Vol. 10, pp. 25567-25585. https://doi.org/10.1039/ D0RA02340

14. Semenishchev V.S., Ryabukhina V.G., Voronina A.V., Mashkovtsev M.A. et al., Journal of Radio analytical and Nuclear Chemistry, 2016, Vol. 309, pp. 583-588.

15. Selim K.A., Youssef M.A., El-Rahiem 
F.H.Abd, Hassan M.S., International Journal of Mining Science and Technology, 2014, Vol. 24, pp. 183-189. https://doi.org/10.1016/j.ijmst. 2014.01.007

16. Selim K.A., Youssef M.A., Hassan M.S., El-Rahiem F.H. Abd., Journal of Ore Dressing, 2013, Vol. 15, pp. 21-32.

17. Niftaliev S.I., PeregudovJu.S., Mokshina
N.Ja., Mjezhri R. Jekologijaipromyshlennost' Rossii, 2019, Vol. 23, No 7, pp. 42-47. https://doi.org/10.18412/1816-0395-2019-7-4247

18. Kravcov A.A., Semenova N.S., Blinov A.V., Jasnaja M.A., et al., Vestnik Kemerovskogo gosudarstvennogo universiteta, 2015, Vol. 3, No 4 (64), pp. 237-244.

Peregudov Yurii S. - associate professor, Department of inorganic chemistry and chemical technology, $\mathrm{PhD}$, Voronezh State University of Engineering Technologies, Voronezh ,e-mail: inorganic 033@mail.ru

Gorbunova Elena M. - associate professor, Department of inorganic chemistry and chemical technology, PhD, Voronezh State University of Engineering Technologies, Voronezh, e-mail: lobanova8686@gmail.com

Rami Mejri - postgraduate student, department of Inorganic Chemistry and Chemical Technology, Voronezh State University of Engineering Technologies, Voronezh e-mail: mezhri@inbox.ru

Niftaliev Sabukhi I. - professor, doctor of science (chemistry), Head of Department of inorganic chemistry and chemical technology, Voronezh State University of Engineering Technologies, Voronezh, e-mail: sabukhi@gmail.com 